\title{
Future of Mobile Learning During and After Global (Covid-19) Pandemic: College of Basic Education as Case
}

\author{
Dr. Yousif H.Alanezi ${ }^{1 *} \quad$ Dr. Nasser S.AlAzwani ${ }^{1,2}$ \\ 1.College of Basic Education, Public Authority of Applied Education and Training \\ 2.Head, Systems Security and Administrations, Sultan Qaboos University
}

\begin{abstract}
The declaration of world health organization (WHO) on March 11, 2020 that the new coronavirus (COVID-19) is a global pandemic has urged countries around the world to impose severe restrictions on their populations in a bid to stop the spread of infection. Imposing social distancing policy has consequence to stop different sectors from daily operations and education one of these sectors. This movement has consequence to accelerate the need for alternative. Mobile learning known as the ability to provide educational content on personal pocket devices, or personal digital assistants (PDAs). This style of learning is in its early stages in terms of both pedagogies and its technologies. M-learning represents a new era in learning and educational development in terms of enhancing the educational outcomes and offering mobile training for employees who are busy off campus. The opposite argument here is that this approach of learning might not be sufficient to fulfill the educational process requirements. Aim of this study is to assess from students points of view, current applications of m-learning in Kuwait's College of Basic Education and evaluate the potential of this approach. Sample of the study consist of fifty-two students (30 male and 22 female) determined by a purposive sampling method. Collected data via online questionnaire to assess the participant's perceptions and the analysis has revealed a positive attitude towards the utilization of m-learning in higher education; the average perception of was above average, with a mean of 3.54 out of 5.00. No statistical differences were found reflecting students' gender (female/ male) or their level of experience with information and communications technology (weak, above average, or advanced). As a result, the study recommends accelerating the development of courses taught and incorporating mobile learning delivery. Adopting a blended learning strategy based on m-learning can motivate the students' learning and reduce the fears of adopting mobile technology within the curriculum.
\end{abstract}

Keywords: Covid-19, M-learning, E-learning, Instructive knowledge, Distance learning

DOI: $10.7176 / \mathrm{JEP} / 11-17-01$

Publication date:June 30th 2020

\section{INTRODUCTION}

The decision to suspend universities, colleges, and education institutes around the world due to declaration of the Coronavirus (COVID-19) pandemic has prompted the discussion regarding necessity and feasibility of learning based on technology methods to the fore, particularly learning based on mobile devices. Whereas, the controversy based on the importance of employing technologies in the educational operations and the usefulness of these approach of education in enhancing knowledge among students has become the subject of wide debate.

Kuwait is not exceptional from this global exceptional situation and similarly has taken the decision to suspend the teaching in-campus and to move to the off campus teaching approach utilizing E-learning. As a state of Kuwait that has invest a lot in developing the education and it was among its top priorities (Altamimi, 2006) need to consider this option. The challenge here to understand the students' capacity and readiness to adopt themselves into this kind of approach.

The attempts in this study is to understand the readiness of student in the College of Basic Education (CBE) for the Mobile learning and their future perceptions regards. This college is affiliated with Kuwait's Public Authority for Applied Education and Training (PAAET). PAAET was established after it became evident that the country had an urgent need for well-trained, skilled personnel. Although training centers existed previously, the quality of their graduates was below the necessary standards, and a large proportion of the workforce was underprepared and not capable of providing the required skills. The need for practical experience and in-service training programs was critical. In addition to its training institutes, four colleges encompass the educational diploma programs with the exception of CBE that grants undergraduate degrees in various fields; CBE - College of Business Studies - College of Health Sciences and College of Technological Studies (PAAET, 2019). These challenges in governing the quality of education within these institutes has also stimulate the need to involve the educational technologies.

For that, CBE seeks to integrate information and communication technologies (ICT) into its classes, and implementing m-learning could be one of the innovative technology employed. The college is fully equipped with advanced computer labs and related digital technologies. All faculty members and students have up-to-date Smartphones and/or other mobile devices equipped with mobile applications that are compatible with online delivery through Learning Management Systems (LMSs). As a general observation, they have access to the tools 
required to implement m-learning in their classes, but there is still a need to assess the students readiness before deploying such as educational technology.

The success of implementing mobile learning (m-learning) for teaching and learning, in teachers' colleges and other higher education sectors, depends largely on the attitudes of faculty and students readiness towards this new technology. The advances in ICT and related software have caused significant transformations in the mobile industry and in how mobile devices are currently used. The term 'm-learning' emerges as a read application for the 21 st century technologies in education and training. Though mobile phones are no longer new, its utilization in education increases day by day. Scope of this study is mainly from the student point of view about current uses of m-learning in the CBE and to explore its future potential.

\section{LITERATURE REVIEW}

Smartphones playing a significant role on a daily human life especially for educators and learners. Individuals depend on smartphones for various activities. This is one of the important reasons for integrating learning and technology, especially on the smartphone technology (m-Learning). There are a several academic evidences supporting the advantages of utilizing m-Learning. Maketo has attempted to (Maketo, 2018) examined the possibility of using m-Learning by studying various factors that influencing the adoption and implementation of m-learning in Zimbabwe. The focus was on the perception of both lecturers and learners towards m-learning and also the challenges associated with the implementation of m-Learning (Maketo, 2018). Their findings led to the development of a new framework for m-Learning particularly for Zimbabwean Universities and the tertiary institutions in other similar developing countries.

Another study been conducted by Pillai and Sivathanu (2018) focussed on applying a novel approach through the use of the behavioural reasoning theory (BRT) to analyse the factors that promote and hinder the adoption of m-Learning applications (Apps) and information technology-enabled services (ITeS). They collected empirical data from 680 employees from the field of Information Technology (IT) and ITeS companies in India. The study identified context-specific factors, such a, self-efficacy, hedonic motivation, ubiquitous and relative advantage, learning autonomy, as contributors to the adoption of m-Learning Apps, and factors such as image barrier and traditional barrier as barriers towards adoption of m-Learning Apps (Pillai and Sivathanu, 2018).

Other study been conducted by Mahande, Susanto, and Surjono (2017) carried out a study in Indonesia that focussed on examining aspects such as dynamics of content, user, and social related to m-Learning. The context of the study in the vocational education based on the FRAME model perspective. The researchers used a random sampling technique and collected data from 103 teachers and 320 students, using questionnaire. The findings revealed that the content that is available on the internet, which are also accessed by teachers, were relevant to the major. However, the students thought that they were relevantly less applicable to their majors. This made the substance and value on the use of m-Learning content as less relevant (Mahande et al. 2017).

Asiimwe, Grönlund, and Hatakka (2017) studied the challenges and practices in an emerging m-Learning environment at Makerere University in Uganda. They collected the data through observations and interviews done with teachers and various m-learning support staff comprising of systems administrators, teacher trainers and a software developer. The focus of their study was on understanding the applicability of learning content management systems (LCMS) and the purposes of m-Learning. They observed the practices of teacher training and m-learning content development and identified teacher skills as an essential factor for the purpose of enhancing educational content, institutional m-learning policies and training programs. The findings therefore contribute to the importance of teaching staff in implementation of new technology, change management, and motivating the support of teachers and students in the use of m-Learning (Asiimwe et al. 2017).

Mobile learning has currently become a common topic in higher educational research, and in many researches of the past, there have been studies on the perspective of staff, parents and students towards $\mathrm{m}$ learning. Taking up a secondary school in England as the centre of study, Li and Liu (2017) analysed the incorporation of iPad-based m-learning into a creative engineering module, using a problem-based learning pedagogy. It was noted that all those who were associated with the creative engineering module possess a somewhat rational and objective view regarding the affordance of the iPad, with the teachers having a relatively positive view about the advantages of iPad-based M-learning in the context of understanding how it has transformed learning fully. The derived results stand as a challenge to the earlier statements that the results of $\mathrm{m}$ learning are quite hard to evaluate, hence, promoting a case-to-case valuation of the results of m-learning. A few disadvantages of the iPad-based m-learning were discovered (Li and Liu, 2017).

Incorporating m-Learning with higher education effectively requires the need for consideration of the factors of both student and educator adoption. Sanderson and Hanbidge (2017), used the data obtained from 309 Canadian university participants through a Mobile Information Literacy (MIL) research study and noted particular student related m-Learning adoption factors and verified it in the literature. The outcome of their research are meant to sustain the educators with focus on pedagogical transformation, to incorporate justifiable $\mathrm{m}$-Learning into their virtual and physical classrooms successfully (Sanderson and Hanbidge, 2017). 
M-Learning has evolved and become a sort of trend in the field of Open and Distance Learning (ODL). It is taking away the barriers of time and geography for learning by opening up opportunities for learning right at the learners' fingertips. M-Learning has been taken up in different forms by ODL institutes in India though it is not used completely due to various reasons. Awadhiya and Miglani (2016) from India studied the challenges that could be encountered by the teachers of Open Universities of India in the application of m-Learning. With reference to this, the teachers of Indian Open Universities were examined to find out and estimate the strength of the different challenges in the successful usage of m-Learning in the ODL system. Having studied a set of respondents $(n=72)$, the results showed that out of almost thirteen (13) challenges which were given to them, the three vital challenges were: (a) the absence of backup for instructional design for m-Learning; (b) the absence of an institutional policy for m-Learning and (c) the lack of infrastructure/technological support. However, these challenges had an extrinsic nature, since they dependent on the institution. The less prominent challenges were: (a) the interference on personal time due to $24 \times 7$ access; (b) hesitancy to adopt technology; and (c) the difficulty of use. These barriers had an intrinsic nature since they were people driven. Irrespective of the gender difference, the challenges of $\mathrm{m}$-Learning were always the same. To successfully implement $\mathrm{m}$-Learning, it is mandatory that institutions offer the required institutional support in relation to the policy, infrastructure and instructional design (Awadhiya and Miglani, 2016).

In other hand, Pfaffe (2014) attempt to use some of explanatory mixed methods to derive the data from the online surveys and personalised interviews of secondary school teachers who have incorporated m-Learning with their teaching. From among the 103 respondents, apart from one who was from Mexico, all the rest from 23 states from across America. Six of the survey respondents were deliberately chosen to participate in a one-on-one phone interview, which was done to clarify and enlarge upon the data derived from the survey responses. The collected data was examined and from the findings it was understood that though many school districts are implementing many kinds of technology, the best practices of m-Learning has yet not been presented, supported and even been developed in the districts' professional development. Most districts don't even support the use of technology integration models like the SAMR model. The outcomes revealed that the respondents developed $\mathrm{m}$ Learning activities mostly at the Enhancement levels (Substitution and Augmentation) than at the Transformational levels (Modification and Redefinition). The main problems that came in the way of creating Transformational m-Learning activities were the absence of training as well as shortage of time. Suggestions had been made to transfer the objective from developing and using technology tools to supporting teachers in designing m-Learning activities (personalized, situated, and connected using a mobile device) that help in the change in learning and the development of 21 st century skills (Pfaffe, 2014).

There is a separation that prevails exists between how students use mobile phones outside their schools for communication and how they utilise them in the classroom. Though there are several m-Learning strategies now, many high schools in the United States have banned their use. Researches have been done in context of $\mathrm{m}$ Learning at the collegiate level, but still a better understanding is required about m-Learning at the secondary level. DeWitte (2010) did a case study to note the change in the attitudes of the teachers as well as students of the secondary Montessori classroom, towards m-Learning following their experience after having used a cell phone in the classroom. The Montessori Method and connectivism gave the adequate theoretical foundation. Through the study could be seen the advantages and limitations concerned with m-Learning, the skills displayed by the 21 st century secondary students while using a cell phone, and the manner in which students utilised their cell phones to sustain a connection with their learning ecology. Adequate data was obtained through both pre and post interviews of teachers and students, text messages, student blog entries and 3 observations. NVivo 8 was used to analyse data to code preliminary categories, and open coding was applied to create themes. From the findings, it was understood that most of the students possessed a positive attitude toward m-Learning. MLearning strategies helped learning; enhanced the increased student productivity; minimized disruption in the classroom; and created scope for "anytime, anyplace" learning. Results of this findings help in guiding educational administrators to make technology policies are apt for the requirements of the stakeholders and offer m-Learning strategies for the teachers which could be successfully incorporated into the classroom (DeWitte, 2010).

2.1 Advantage and disadvantages of m-learning

Alhassan (2019) went on to discover the level of readiness and attitudes as well as the possible obstacles that come in the way of using m-Learning as a section of global learning. He also tried to understand the extent of the interest of the students in m-Learning. Another promising objective of the study was to see if the college students were actually ready to use m-Learning technologies. The study was done to collect the valuable data related to the possible advantages and disadvantages of m-Learning, and also the obstacles that may be encountered by the students while using m-Learning technologies. He carried out this research by distributing a questionnaire out to 1000 college students, out of which, he interviewed a few for in-depth information. From the study it was derived that the students had great amount of positive attitudes toward m-Learning, and they also had the 
appropriate technical knowledge to use m-Learning. Yet, the students did not have much experience in mobile and electronic learning. A major benefit seen by the students in the context of m-Learning was that they could do their learning at any time, outside the classroom. A noted disadvantage is that students could get irritated with receiving too many text messages frequently. Students also pointed out certain barriers that they assume to face while implementing m-Learning. The conclusion of the study highlighted the suggestions for future research and recommendations to university officials to apply m-Learning in a better way (Alhassan, 2019).

During different type of unpredictable crises, education service disrupted and this becomes a big challenge for universities, schools, communities, international agencies and governments. Baytiyeh (2019) had pointed out that in such cases of crises; the mobile technologies seem to have a strong role for supporting in the consistent education delivery if the school would have temporary closures. He explained as to how school administrators can help minimize the effect on students. An interactive online educational environment is described in the article highlighting the advantages of the m-Learning devices for this cause. He summarized his article saying that with the aid of proper training, teachers would be able to incorporate m-Learning tools in both classroom activities as well as out-of-classroom learning. The article highlighted the point of interest to educational policy makers and school administrators with the objective of confirming consistent education delivery consequent to the major crises (Baytiyeh, 2019).

There are numerous studies done on m-Learning, yet hardly any attention has been given to the functions of self-management of learning and personal learning initiative on mobile English learning outcomes. Huang and Chung-Long (2019) analyzed the connection between self-management of learning, perceived flexibility advantage, mobile English learning continuance intention and performance; they also searched on the controlling role of personal learning initiative in mobile language learning outcomes. 323 undergraduate students having mobile English learning experience participated in this study. To assess this data, the partial least-squares structural equation modeling analysis and SPSS PROCESS (model 7) were used. Not only did the results of the study indicate that the perceived flexibility advantage and self-management of learning will have an affirmative impact on mobile English learning continuance intention and performance, but it also showed that mobile English learning continuance intention would facilitate the connection between perceived flexibility advantage and mobile English learning performance. It was also noted that personal learning initiative would play a facilitating part in strengthening the positive relationship between perceived flexibility advantage and mobile English learning continuance intention (Huang and Chung-Long, 2019).

When on the one hand, the already present research focuses on either the benefits of implementing mobile technologies for teaching and learning languages or on how mobile learners with mixed cultural and linguistic backgrounds, connect the aids of technologies to learn new languages, on the other hand, some studies look at both the perspectives. Ho (2018) submitted his report on a study of self-directed language learning in online platforms. He particularly studied the manner in which mobile technologies, for example, online language learning platforms, mold the learning practices of mobile learners, and how the mobile learners benefit from the affordances of these online platforms to gain their own learning goals, in relation to learning Chinese as a foreign language. Making a detailed analysis of two case studies, the author stated that it might seem that mobile technologies foster a vivid differentiation between online and offline learning, but, actually, the boundary is not clear-cut since mobile learners introduce certain offline learning practices from their own experiences into the online environment (Ho, 2018).

Mahdi (2018) has reported a meta-analysis study with regard to the success of the use of mobile devices on vocabulary learning. In the meta-analysis was studied how effect sizes deferred according to the learners' age, kind of vocabulary learning (receptive or productive), and parts of vocabulary used (form, meaning, and use). This meta-analysis studied the impact of applying mobile devices for vocabulary learning by examining 16 studies that had around 986 participants. The application of mobile devices in learning vocabulary was linked with much greater achievement when compared to the traditional ways. The outcome of the meta-analysis implies a medium impact of the application of mobile devices on vocabulary learning ( $g=0.67)$. The main highlight of the current meta-analysis comprised the following facts : (a) Mobile devices have moderate effect sizes in relation to both kinds of vocabulary learning (productive and receptive), (b) adult learners benefit from using mobile devices in vocabulary learning in a more better way than young learners, and (c) mobile devices have a moderate effect on every aspect of vocabulary learning (Mahdi, 2018).

Though much focus has been given to m-Learning studies, yet, there still seems to be a shortage in the studies that investigate the moderating effect of proactive personality on m-Learning achievements. Huang, Tang, Lee, and Yang (2017) searched for the main elements that would help enhance the efficiency and effectiveness of $\mathrm{m}$-Learning; along with also they examining the moderating role of proactive personality in $\mathrm{m}$-Learning outcomes. The study results showed that continuance intention will positively impact $\mathrm{m}$-Learning performance, while the perceived liveliness would have only a small impact on m-Learning outcomes. Perceived flexibility advantages will also affect m-Learning continuance intention and perceived playfulness, positively. In the context of the role of perceived usefulness in perceived playfulness, the outcome showed that though perceived 
usefulness has an affirmative impact on continuance intention, it has a short impact on perceived playfulness Finally, the results also showed that proactive personality has a moderating function to play in the association between perceived playfulness and m-Learning performance, the relation between perceived flexibility advantages and mobile learning continuance intention, the relationship between perceived usefulness and $\mathrm{m}$ Learning continuance intention, and the link between perceived usefulness and playfulness (Huang et al. 2017).

The research conclusions can be summarize the main advantages and disadvantages of $\mathrm{m}$-Learning, that are discussed here. M-Learning gives good learner engagement and greater completion rates. The main advantages of m-Learning are (Huang et al. 2017):

1. Learning on the go: Nowadays, learners do not prefer to sit at their office desk and learn. Hence, the greatest advantage of m-Learning is the distinctive facility to offer anytime-anywhere learning.

2. Multi-device support: As put in the definition, m-Learning designs helps in all of the needs and uses of all device learners. The same courses are applicable on laptops/desktops and tablets/smartphones.

3. Flexibility to learners: m-Learning provides great flexibility to learners to select the choose the device that they wish to learn on, when they want to do so and also at what speed they intend to consume and adapt.

4. Interesting design formats to learn from: m-Learning have certain design formats that the learners are familiar with and also develop a better maintenance and recall, these formats comprise those that are common on our smartphones (videos, interactive videos, animated videos and so on).

5. More options to create engaging learning: Micro learning has modified the style of training delivery. Currently, it is mostly used to provide formal training and as a section of the ecosystem to enhance informal learning. It is possible to have micro learning nuggets on mobile devices, in the same way, as it is possible to incorporate Mobile Apps for learning in the overall strategy.

To wrap up the literature, it has to be acknowledged that $\mathrm{m}$-Learning is a vital part of the learning strategy of almost all higher education institutions and training organizations. With micro learning developing to be the more preferred option for both formal and informal learning, the adoption of m-Learning will gain much pace in the future. Considering it as a preferred electronic learning (e-Learning) delivery, m-Learning is regarded presently as the most self-paced, highly learner-centric learning on the go. Now, it has become a crucial part of training delivery and becomes vital for meeting the training needs for both formal and informal learning. This innovative technology encourages social or collaborative learning and training activities. So, looking at how the training will be consumed, it has become possible for a person to select between mobile-friendly (adaptive designs) and mobile first (fully responsive designs).

The general research summarized the main advantages of mobile learning as follows (Huang et al. 2017):

- Learning on the go: Nowadays, since learners do not prefer to sit at their office desk to learn, they find the biggest advantage of mobile learning with its special feature to offer anytime-anywhere learning on the go.

- Multi-device support: According to definition, mobile learning designs sustains all devices learners need and their use, which is the same for laptops/desktops and tablets/smartphones also.

- Flexibility to learners/trainees: Mobile learning provides great level of flexibility to learners/trainees to select which device they wish to learn on, when they want to learn and at what speed they want to consume and adapt to it.

- Interesting design formats to learn from: Mobile learning have certain design formats that the learners are familiar with which provides better retention and recall. These also comprise formats that we use frequently on our smart phones (videos, interactive videos, animated videos and so on).

More options to create engaging learning: Micro learning has modified the style of training delivery. Currently, it is mostly used to provide formal training and as a section of the ecosystem to enhance informal learning. It is possible to have micro learning nuggets on mobile devices, in the same way, as it is possible to incorporate Mobile Apps for learning in the overall strategy.

The m-Learning disadvantages are related various. For example, m-Learning is to be accessed on smartphones that have a limitation on the screen size. This can hinder and be an inconvenience in reading large amount of learning content. Extensive focus on small screen can also lead to strain on the eye. Smartphones can handle several activities on interest, such as social media, text messages, news alerts, etc., that are delivered immediately. This can lead to distractions from the prime intention of learning and take a negative impact on the learning experience. Another disadvantage pertains to the hardware - the smartphone itself. These devices rely heavily on batteries and the need for continuous internet connectivity. Limitations and hindrances in any of these can also lead to hindrance to the learning experience. Standardization can be another issue that demotivates or hinder the m-Learning experience. The growth of smartphones has attracted several smartphone manufacturers and operating systems (OS). This means that m-Learning providers have to consider different OS platforms and smartphone devices to ensure that their m-Learning Apps are compatible. Inability of doing so, can limit the use and acceptance of $m$-Learning. 


\section{THE STUDY}

3.1 Research Problem

Because of mobile utilization in our modern daily live, m-learning represents the current extension of e-learning and has more potential to make learning widely available and more accessible. It offers opportunities for optimizing the field of educational technology, whose principles and methods are in turn used to develop learning material for all other sciences. In addition, shed the lights over the advantages of this type of learning in maintaining education process during any global pandemic similarly to what has occurred in (COVID-19).

The challenge here is up to what extend the students are ready to merge their traditional skills and willingness to study with the newly assumed approaches. The investigation mainly depends on assessing the perceptions of year four students regarding m-learning. Core question is to response to: How do CBE students perceive the current uses and future of mobile learning in higher education?

Emerging the following sub-questions:

1. What is the overall perception of $\mathrm{CBE}$ students concerning m-learning, in terms of its current and future application to higher education?

2. Do these perceptions vary according to gender (male/female)?

3. Do these perceptions vary according to level of ICT experience (weak/above average/advanced)?

4. What are the advantages of m-learning, from the participants' points of view?

5. What are the disadvantages of m-learning, from the participants' points of view?

\subsection{Study Objectives}

Main objectives from conducting this study is to respond to the listed below objectives. These objectives aim to answer the listed question via accomplishing these objectives:

1. Assess the overall perception of Kuwait's CBE students concerning m-learning, in terms of its current and future application to higher education.

2. Explore the variation in the participants' perceptions based on their gender and experience in ICT.

3. Derive a list of m-learning advantages from the CBE students' points of view.

4. Derive a list of m-learning disadvantages from the CBE students' points of view.

5. Generate recommendations for m-learning future applications in the CBE.

Accomplishing these objectives will assist reader to correlate what is been assumed as a research problem with the data and results.

\subsection{Significance of the Study}

The significance of this study lies in its attempt to:

1. Map the CBE students' perception of current and future applications of m-learning, and deal with their readiness for m-learning utilization.

2. Motivate the CBE Educational Technology students to practice using m-learning in their own time in a more interactive way.

3. Plan a blended learning strategy based on m-learning for teaching Educational Technology at CBE, to attract students and motivate their learning.

4. Provide evidence of the effectiveness of m-learning in higher education.

5. Inform stakeholders and teaching staff at CBE about the importance of m-learning and its future in Kuwait's higher education.

\subsection{Study Limitations}

Scope of the study was predefined earlier and results gained can only be generalized under the following limitations:

1. Human limitations: Educational Technology students.

2. Institutional limitations: the CBE, affiliated with the PAAET in Kuwait.

3. The time limitations: Summer semester of 2020.

4. Explore and assess the present and the future status of m-Learning from the point of view of CBE Educational Technology students.

\section{METHODS AND PROCEDURES}

The methodology of the study was based on an online survey technique. A list of questions and their corresponding answers, both delivered online; they are used frequently to collect the opinions of students in higher education. Park, Park, Heo, and Gustafson (2019) investigated the factors associated with students' willingness to respond to online surveys. Around 540 undergraduate and graduate students in the U.S. participated in the study. Factor analysis was conducted to categorize the reasons that students willingly participate in online surveys, and three factors were identified: Format, Affiliation, and Content. The regression 
analysis revealed that the type of format significantly affected the participation of undergraduate students in online surveys, whereas the content was significantly related to the participation of graduate students; therefore, the response to online surveys may vary depend on participants' educational level. The findings suggested that in order to boost response rates, multiple strategies may be needed when designing online surveys for educational purposes. For example, Smith (1997) found that when a Web-based survey was preceded by an email inviting individuals to the URL to participate, the Web-based survey significantly outperformed email survey participation.

Online surveys are increasingly utilised in educational research, yet little attention has been given to the ethical issues associated with their use in educational settings. Roberts and Allen (2015) drew on the broader literature to discuss five key ethical issues in the context of educational survey research: dual teacher/researcher roles; informed consent; use of incentives; privacy, anonymity, and confidentiality; and data quality. They recommended adopting a situated/process ethics approach to identify and respond to ethical issues that might arise during the conduct, analysis, and reporting of online survey research. They also highlighted the benefits of online surveying in comparison to traditional survey methods, including the potential for online surveys to provide ethically defensible methods of conducting research that would not be feasible in offline education research settings.

Kobayashi (2015) investigated the perceptions regarding the ease of use and usefulness of Google Hangouts as an instructional/learning tool. Forty-two teacher education students at U.S. and Japanese universities participated in an online cross-cultural activity using Google Hangouts, during which they discussed cultural differences between the two countries and their teaching philosophies. Afterwards, the students responded to a survey, which also collected qualitative data about their overall learning experience. The results indicated that Google Hangouts was a useful instructional tool but was not easy to use. Although technical problems occurred during the conference, the activity provided valuable experiences for both groups of students.

The process of delivering and conducting the online survey for the current research involves the following steps:

1. Devising a set of questions and the options for responding to these questions (e.g. discrete options or a range of choices for closed questions, and a text box for open questions). The subjects of these questions are college students' perception of m-learning and its usage in college-level.

2. Delivering the questions in an online format using Google survey software.

3. Publishing and promoting the survey to achieve a suitable, balanced, representative sample of respondents from a target population (CBE Educational Technology students).

4. Collecting the data.

5. Data Analysis and its correlation to research questions

The researcher adopted an online survey research method to map the CBE students' perception of current applications and the future of $\mathrm{m}$-learning and deal with their readiness for m-learning utilization in Kuwait.

\subsection{Instrumentation}

The selected society for instrumenting the study are directly in contact with the need of mobile eLearning. The aim of the scale is to collect the data needed to assess the perception of CBE students towards the present and the future of m-learning in higher education. A five-point Likert scale was used to judge the participants' responses, with the levels specified as: strongly agree, agree, undecided, disagree, and strongly disagree. Scores from 5 to 1 were assigned for positive responses, while the negative responses were assigned 1 to 5 .

The mobile learning survey was composed of three parts. Part One aimed to collect personal information about the participants; Part Two was the m-learning questionnaire, composed of 30 statements and three subdimensions including the willingness to use m-learning, and the disadvantages of M-learning that hinder its use; and Part Three consisted of 12 open-ended questions distributed among four categories related to mobile uses and applications - i.e., connecting, communicating, collaborating and creating personalized learning (Table 1).

Table 1: Distribution of the m-learning statements on the sub-dimensions

\begin{tabular}{|r|l|l|}
\hline$\#$ & Scale sub-dimension & Item/statement numbers \\
\hline 1. & Willingness to use M-learning & $1,2,3,4,5$, and 6 \\
\hline 2. & Advantages of M-learning & $7,8,9,10,11,12,13,14,15,16,17$ and 18 \\
\hline 3. & Disadvantages of M-learning & $19,20,2122,23,24,25,26,27,28,28,29$ and 30. \\
\hline 4. & The whole scale & $1,2,3,4,5,6,7,8,9,10,11,12,13,14,15,16,17,18,19,20$, \\
& & $2122,23,24,25,26,27,28,28,29$ and 30. \\
\hline
\end{tabular}

To assure the validity of the content in the m-learning questionnaire, the instrument was reviewed and judged by a committee of four experts in e-learning and Educational Technology (a professor of instructional technology and distance education, an associate professor in e-learning and distance training, an assistant professor in Educational Technology and e-learning development, and an expert lecturer in distance education with a B.Sc. in computer science who works as a Virtual Learning Environment administrator and distance 
learning developer. The team's suggestions for validating and improving the instrument were considered, and an improved version was submitted for a second review. The computed value of Cronbach's Alpha for the whole scale was found to be (.786).

Population and Sample:

The proposed population of the present study covering CBE students who were studying educational technology during the academic year 2018/2019. The sample consisted of 52 instructional technology students who registered for the 2019 summer semester in the CBE. Around 57.7\% (30) of the participants' were males, while 42.3\% (22) were females. Their Grade Point Averages (GPAs) ranged from 1.98 to 3.77, with a mean $=2.721$ and Std. $=.48385$. Concerning their experience in ICT, $3(5.8 \%)$ rated their level of ICT experience as being weak, $35(67.3 \%)$ as above-average, and $14(26.9 \%)$ as advanced.

\section{RESULTS}

Main question addressed in this study: How do CBE students perceive the current and future use of mobile learning in higher education?.

Response was within the answers of the sub-questions listed below; collected data were analysed utilising SPSS software for assuring accuracy as well as structure of related information.

5.1Results related to Question 1

Question 1: What is the overall perception of CBE students of m-learning current applications and future potential in Kuwait higher education?

The CBE students' overall perception of m-learning current applications and future potential in Kuwait was assessed by collecting the related data and analysing it by using SPSS software. Table 2 presents the descriptive statistics results, while Table 3 shows One-Sample Test Results.

Table 2: Descriptive Statistics

\begin{tabular}{|l|c|c|c|c|c|}
\hline \multicolumn{1}{|c|}{ Scale dimension } & $\mathrm{N}$ & Minimum & Maximum & Mean & SD \\
\hline Willingness to use m-learning & 52 & 1.17 & 4.83 & 3.5192 & .76101 \\
\hline Advantages of m-learning & 52 & 1.42 & 5.00 & 3.9003 & .93095 \\
\hline Disadvantages of m-learning & 52 & 1.00 & 5.00 & 3.1748 & .78444 \\
\hline The Scale & 52 & 2.23 & 4.83 & 3.5366 & .49680 \\
\hline
\end{tabular}

Table 2 shows the results of the students' responses on the mobile learning perception questionnaire. The advantages of m-learning scored the highest rating $(\mathrm{M}=3.9003, \mathrm{SD}=.93095)$, while the disadvantages of $\mathrm{m}$ learning scored the lowest $(\mathrm{M}=3.1748, \mathrm{SD}=.7844)$, which is not far from the average (normal) perception of 3 out of a 5 point scale.

To test how the students judge their perceptions of m-learning current uses and future in Kuwaiti higher education, a one-sample test was run (Table 3).

Table 3: One-Sample Test Results

\begin{tabular}{|c|c|c|c|c|c|c|}
\hline \multirow{3}{*}{ The Scale dimension } & \multicolumn{6}{|c|}{ Test Value $=3$} \\
\hline & \multirow[b]{2}{*}{$\mathrm{t}$} & \multirow[b]{2}{*}{$\mathrm{df}$} & \multirow{2}{*}{$\begin{array}{c}\text { Sig. } \\
(2- \\
\text { tailed })\end{array}$} & \multirow{2}{*}{$\begin{array}{c}\text { Mean } \\
\text { Difference }\end{array}$} & \multicolumn{2}{|c|}{$\begin{array}{l}\text { 95\% Confidence Interval of the } \\
\text { Difference }\end{array}$} \\
\hline & & & & & Lower & Upper \\
\hline $\begin{array}{l}\text { Willingness to use m- } \\
\text { learning }\end{array}$ & 4.920 & 51 & .000 & .51923 & .3074 & .7311 \\
\hline $\begin{array}{l}\text { Advantages of } \mathrm{m}- \\
\text { learning }\end{array}$ & 6.906 & 50 & .000 & .90033 & .6385 & 1.1622 \\
\hline $\begin{array}{l}\text { Disadvantages of } \mathrm{m}- \\
\text { learning }\end{array}$ & 1.592 & 50 & .118 & .17484 & -.0458 & .3955 \\
\hline The Scale & 7.714 & 50 & .000 & .53660 & .3969 & .6763 \\
\hline
\end{tabular}

Mobile learning perception for the sample of CBE students studying Educational Technology during the summer of 2019 was statistically different, at the .05 of significance, from the normal perception mean value of 3 . For the whole scale $(\mathrm{M}=3.5366, \mathrm{SD} .49680, \mathrm{n}=52,95 \%$ on mean difference $=.3969$ to $.6763, \mathrm{t}=7.714, \mathrm{df}=$ $50, \mathrm{p}<.05)$. The results show that the CBE students have a higher mean on m-learning perception than the normal nationwide.

5.2Results related to Question 2

Question 2: Do student's perceptions of m-learning vary according to their gender?

To assess the variation in students' perceptions of m-learning according to gender, independent samples t-test was administered. Table 4 and Table 5 show the results of this test. 
Table 4: Group Statistics based on student's gender

\begin{tabular}{|l|l|l|l|l|}
\hline \multirow{2}{*}{ Willingness to use m-learning } & Gender & $\mathrm{N}$ & Mean & SD \\
\hline \multirow{2}{*}{ Advantages of m-learning } & male & 30 & 3.6000 & .67891 \\
\cline { 2 - 5 } & female & 22 & 3.4091 & .86484 \\
\hline \multirow{2}{*}{ Disadvantages of m-learning } & male & 30 & 4.0431 & .74656 \\
\cline { 2 - 5 } & female & 22 & 3.7121 & 1.12032 \\
\hline \multirow{2}{*}{ The Scale } & male & 30 & 3.2098 & .71187 \\
\cline { 2 - 5 } & female & 22 & 3.1288 & .88630 \\
\cline { 2 - 5 } & male & 30 & 3.6264 & .37090 \\
\cline { 2 - 5 } & female & 22 & 3.4182 & .61513 \\
\hline
\end{tabular}

Table 4 indicates that the means of male students were higher than those of female students in all dimensions of the scale, as well as the whole scale. To test whether or not these differences in means are of significant values, an independent samples t-test was run (Table 5).

Table 5: Independent Samples Test based on student gender (male-female)

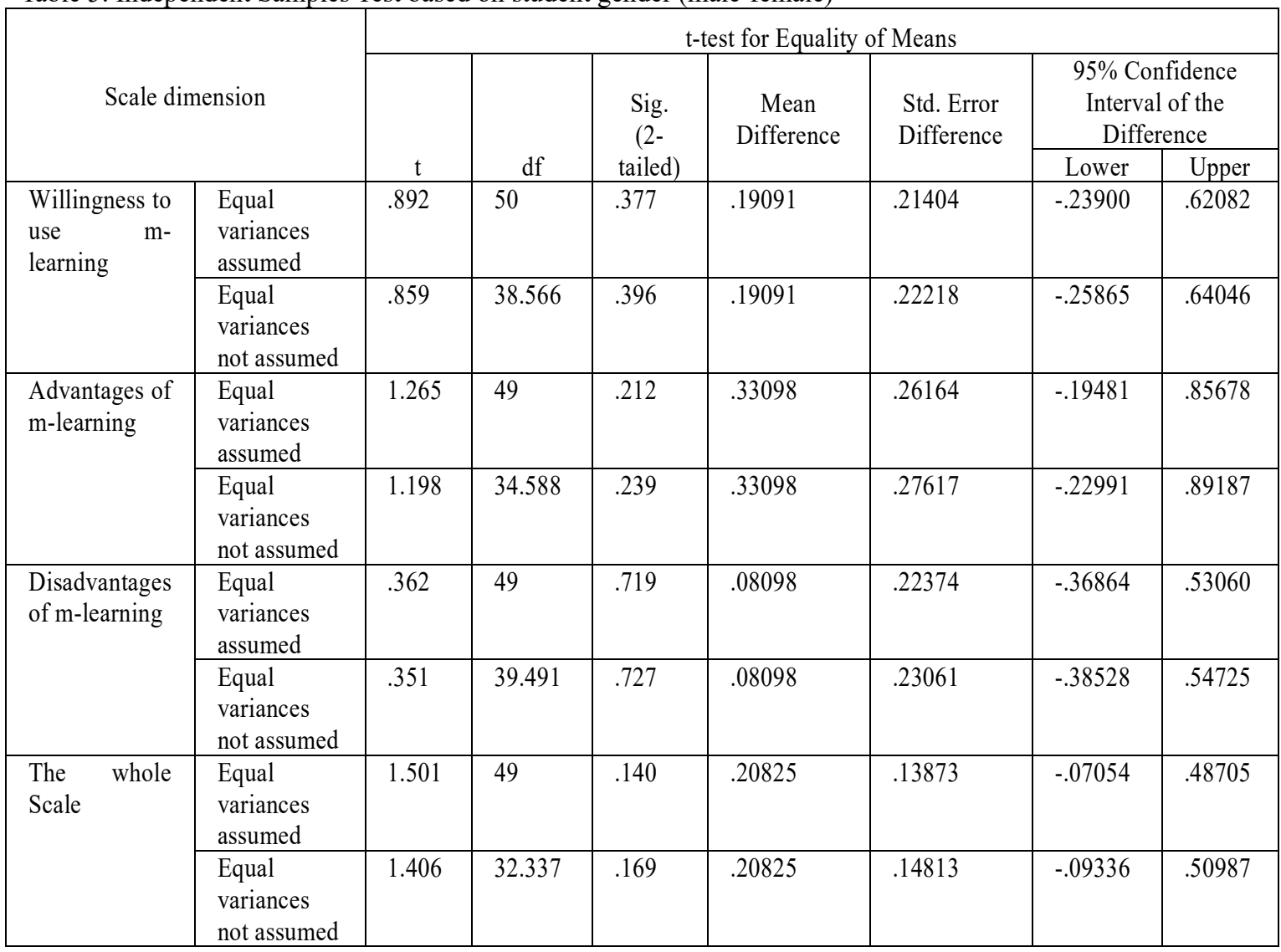

An independent-samples t-test was conducted to compare CBE male students' perceptions of m-learning with those of female students. There were no significant differences in the scores for male $(M=3.6264$, $\mathrm{SD}=.37090)$ and female $(\mathrm{M}=3.4182, \mathrm{SD}=.61513)$ conditions; $\mathrm{t}(49)=1.501, \mathrm{p}=0.140$. These results suggest that there were no significant differences in students' means rating on M-learning perceptions (the whole scale mean) due to their gender, as well as sub-dimensions of m-learning scale, including willingness to use m-learning, advantages of m-learning and disadvantages of m-learning.

5.3 Results related to Question 3

Question 3: Do students' perceptions of m-learning vary according to their level of experience in ICT?

Table 6 shows the descriptive statistics of the participants' m-learning perception according to their experience in ICT, while Table 7 shows ANOVA test results based on students' experience in ICT (weak, average, advanced) respectively. 
Table 6: Descriptive Statistics of the participants ' m-learning perception based on ICT experience

\begin{tabular}{|c|c|c|c|c|c|c|c|c|}
\hline \multirow{2}{*}{\multicolumn{2}{|c|}{ ICT Experience Level }} & \multirow{3}{*}{$\begin{array}{l}\mathrm{N} \\
3\end{array}$} & \multirow{3}{*}{$\begin{array}{l}\text { Mean } \\
3.2222\end{array}$} & \multirow{3}{*}{$\begin{array}{c}\text { SD } \\
.09623\end{array}$} & \multicolumn{2}{|c|}{$\begin{array}{l}95 \% \text { Confidence } \\
\text { Interval for Mean }\end{array}$} & \multirow{3}{*}{$\begin{array}{l}\text { Min } \\
3.17\end{array}$} & \multirow{3}{*}{$\begin{array}{l}\text { Max } \\
3.33\end{array}$} \\
\hline & & & & & \multirow{2}{*}{$\begin{array}{l}\text { Lower } \\
\text { Bound } \\
2.9832 \\
\end{array}$} & \multirow{2}{*}{ 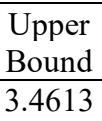 } & & \\
\hline Willing to use & Weak & & & & & & & \\
\hline M-learning & Above average & 35 & 3.5238 & .78293 & 3.2549 & 3.7928 & 1.17 & 4.83 \\
\hline & Advanced & 14 & 3.5714 & .80254 & 3.1081 & 4.0348 & 1.83 & 4.33 \\
\hline & Total & 52 & 3.5192 & .76101 & 3.3074 & 3.7311 & 1.17 & 4.83 \\
\hline \multirow{4}{*}{$\begin{array}{l}\text { Advantages of } \\
\text { M-learning }\end{array}$} & Weak & 3 & 3.3056 & .41944 & 2.2636 & 4.3475 & 2.92 & 3.75 \\
\hline & Above average & 34 & 3.9681 & .78684 & 3.6936 & 4.2427 & 2.17 & 5.00 \\
\hline & Advanced & 14 & 3.8631 & 1.28044 & 3.1238 & 4.6024 & 1.42 & 5.00 \\
\hline & Total & 51 & 3.9003 & .93095 & 3.6385 & 4.1622 & 1.42 & 5.00 \\
\hline \multirow{4}{*}{$\begin{array}{l}\text { Disadvantages } \\
\text { of M-learning }\end{array}$} & Weak & 3 & 3.6389 & .26788 & 2.9734 & 4.3043 & 3.33 & 3.83 \\
\hline & Above average & 34 & 3.1520 & .69099 & 2.9109 & 3.3931 & 1.00 & 4.42 \\
\hline & Advanced & 14 & 3.1310 & 1.04427 & 2.5280 & 3.7339 & 1.33 & 5.00 \\
\hline & Total & 51 & 3.1748 & .78444 & 2.9542 & 3.3955 & 1.00 & 5.00 \\
\hline \multirow{4}{*}{$\begin{array}{l}\text { The whole } \\
\text { scale }\end{array}$} & Weak & 3 & 3.4222 & .23649 & 2.8348 & 4.0097 & 3.17 & 3.63 \\
\hline & Above average & 34 & 3.5569 & .45649 & 3.3976 & 3.7161 & 2.57 & 4.20 \\
\hline & Advanced & 14 & 3.5119 & .63792 & 3.1436 & 3.8802 & 2.23 & 4.83 \\
\hline & Total & 51 & 3.5366 & .49680 & 3.3969 & 3.6763 & 2.23 & 4.83 \\
\hline
\end{tabular}

Table 7: ANOVA test results based on students' experience in ICT

\begin{tabular}{|c|c|c|c|c|c|c|}
\hline & & $\begin{array}{l}\text { Sum of } \\
\text { Squares }\end{array}$ & df & Mean Square & $\mathrm{F}$ & Sig. \\
\hline \multirow{3}{*}{$\begin{array}{l}\text { Willing to use } \\
\text { M-learning }\end{array}$} & Between Groups & .304 & 2 & .152 & .254 & .776 \\
\hline & Within Groups & 29.233 & 49 & \multirow{2}{*}{.597} & & \\
\hline & Total & 29.536 & 51 & & & \\
\hline \multirow{3}{*}{$\begin{array}{l}\text { Advantages of } \\
\text { M-learning }\end{array}$} & Between Groups & 1.237 & 2 & .619 & .705 & .499 \\
\hline & Within Groups & 42.097 & 48 & \multirow{2}{*}{.877} & & \\
\hline & Total & 43.334 & 50 & & & \\
\hline \multirow{3}{*}{$\begin{array}{l}\text { Disadvantages } \\
\text { of M-learning }\end{array}$} & Between Groups & .691 & 2 & .345 & .551 & .580 \\
\hline & Within Groups & 30.077 & 48 & \multirow{2}{*}{.627} & & \\
\hline & Total & 30.767 & 50 & & & \\
\hline \multirow[t]{3}{*}{ The whole scale } & Between Groups & .062 & 2 & .031 & .121 & .887 \\
\hline & Within Groups & 12.279 & 48 & \multirow{2}{*}{.256} & & \\
\hline & Total & 12.341 & 50 & & & \\
\hline
\end{tabular}

From Tables 6 and 7 above, it can be seen that there are no significant differences in the perception of CBE students towards m-learning due to their experience in ICT. For the whole scale, the computed F $(2)=.121$, $\mathrm{p}=.121$ ), which is above 0.05 ; therefore, there is no statistically significant difference in students' perception of m-learning means associated with their level of ICT experience.

5.4 Results related to Question 4

Question 4: What are the advantages of m-learning, from the participants' points of view?

The advantages reported most by the participants are summarized as follows:

1. M-learning is the technology of the digital age; it can expand the instructional time outside the class and facilitate more interaction.

2. It saves effort and time.

3. I feel somewhat comfortable with m-learning, but it needs to be adapted to our educational system.

4. Using m-learning through my personal phone facilitates communications with my instructor and my colleagues.

5. It helps me to make better use of my free time.

5.5 Results related to Question 5

Question 5: What are the disadvantages of m-learning, from the participants' points of view?

The disadvantages reported by the participants can be summarized into:

1. The college instructional system needs to be updated before it hosts m-learning delivery, 
2. Online course development should be compatible with the current and up-to-date mobile applications,

3. Instructional communications should be carried out under smart phones application between the lecturer and the students,

4. M-learning might reduce teamwork inside the classroom,

5. Though it is a wonderful technology, possible idea however hinders students' assessment and evaluation,

6. Navigating the online course through mobiles is sometimes slow and difficult to browse,

7. It is not applicable for practical work and in-class activities,

\section{DISCUSSION AND CONCLUSION}

The need to accelerate the implementation of different e-learning approach has been confirmed by the consequence of the global COVID-19 pandemic. In response to this exceptional or similar situation, mobile learning as approach involves any kind of learning that occurs on a mobile device, whether that refers to tablets, laptops, or smartphones; it can refer to anything from listening to podcasts to reading articles to completing a full e-learning course. This study has assess the perceptions of CBE students about the current and future uses of mobile learning in higher education. Before assessing the students' perceptions of mobile learning, the study highlighted education in the state of Kuwait and the CBE, a national teacher training institution seeking to integrate ICT into its classes.

Technically, it is worth mentioning that the increasing availability of Internet connectivity and interactive mobile and web applications has contributed to the growth in the number of universities and colleges implementing m-learning for teaching and training purposes, even though this is process need further enhancement in term of awareness an training. When designing courses, educators must determine how to develop the learning material and how to integrate m-delivery in their classes.

Overall, the analysis revealed that the CBE students in Kuwait have a good perception about current and future uses of m-learning in higher education; this it can be said that the CBE students are ready to join and benefit from the m-learning courses. Although the male students' means were greater than the female means in the whole scale of m-learning perceptions as well as the sub-diminutions, data analysis revealed no statistical differences related to gender or experience in ICT.

Expected benefits as well as the disadvantages of m-learning as reported by the participants are very similar to those reported within research literature. This result indicated that the CBE students were aware of the benefits and disadvantages of mobile technology applications for learning and training, and that they possess above average perception of mobile learning utilization in higher education as well as experience in ICT at a level that made them ready for m-learning implementation in their education. This result is supported by Li and Liu (2017), whose investigation found that that all those who were involved in the creative engineering module had a relatively objective and rational opinion of the advantages of the iPad, and the teachers were generally positive about the benefits of iPad-based m-learning when discussing how it had changed learning as a whole.

For better m-learning outcomes at the CBE, academic staff members and students must be trained to use such technology and must work collaboratively and take equal ownership in determining the best m-learning principles for college students. The CBE administration should continue to make use of digital technologies and innovations that can motivate the students to benefit from m-learning in their classes. Supporting this approach, an Indian study by Pillai and Sivathanu (2018) found that the context-specific adoption factors for m-learning apps were hedonic motivation, self-efficacy, learning autonomy, ubiquitous and relative advantage, whereas the reasons against the adoption of the m-learning apps are traditional barrier, usage barrier and image barrier.

In summarising the recommendations reflecting the study results, there is wide benefits can be gained. The list of recommendation is:

1. Modernizing the courses taught at the CBE so they are adapted to mobile learning delivery.

2. Recommending a blended learning strategy, based on m-learning, which motivates the students' learning and removes their fears and worries concerning the integration of technology into the college curriculum.

3. Invest more in training and motivating the academic staff aligned with the students to utilise m-learning in their classes.

4. Encourage and help the students in practicing m-learning and reporting the related challenges.

5. Continuing updates to the CBE LMS and the associated methods of course delivery based on the College Strategy.

Acknowledgement: The authors would like to thank the CBE Educational Technology students who participated in this study. 


\section{REFRENCES}

- Alhassan, Riyadh (20192016). Mobile Learning as a Method of Ubiquitous Learning: Students' Students' Attitudes, Readiness, and Possible Barriers to Implementation in Higher Education. Journal of Education and Learning, v5 n1 p176-189 2016.

- Altamimi, A. (2006). Researches in Kuwait History. Kuwait City, Kuwait: Qurtas Press.

- Asiimwe, Edgar Napoleon; Grönlund, Åke; Hatakka, Mathias (2017). Practices and Challenges in an Emerging M-Learning Environment. International Journal of Education and Development using Information and Communication Technology, v13 n1 p103-122 2017.

- Awadhiya, Ashish Kumar; Miglani, Anshu (2016). Mobile Learning: Challenges for Teachers of Indian Open Universities. Journal of Learning for Development, v3 n2 p35-46 2016.

- Baytiyeh, Hoda (2019). Mobile Learning Technologies as a Means of Maintaining Education Delivery in Crisis Situations. International Journal of Information and Communication Technology Education, v15 n3 Article 1 p1-10 2019.

- Crompton, H. (2013). "A historical overview of mobile learning: Toward learner-centered education". In Z. L. Berge \& L. Y. Muilenburg (Eds.), Handbook of mobile learning (pp. 3-14). Florence, KY: Routledge.

- DeWitte, Cynthia M. (2010). Integrating Cell Phones into the Secondary Montessori Classroom. ProQuest $L L C$, Ph.D. Dissertation, Walden University.

- Higher Education in Kuwait (October, 2003). Arab International Women's Conference, 22 October 2003.

- Ho, Wing Yee (20192018). Mobility and Language Learning: A Case Study on the Use of an Online Platform to Learn Chinese as a Foreign Language. London Review of Education, v16 n2 p239-249 2018.

- Huang, Rui-Ting; and Yu, Chung-Long (20192018). Exploring the Impact of Self-Management of Learning and Personal Learning Initiative on Mobile Language Learning: A Moderated Mediation Model. Australasian Journal of Educational Technology, v35 n3 p118-131 20192018.

- Huang, Rui-Ting; Tang, Tzy-Wen; Lee, Yi Ping; and Yang, Fang-Ying (2017). Does Proactive Personality Matter in Mobile Learning? Australasian Journal of Educational Technology, v33 n2 p86-96 2017.

- Kobayashi, Michiko (2015). Students' Evaluation of Google Hangouts through a Cross-Cultural Group Discussion Activity. Turkish Online Journal of Distance Education, v16 n2 p28-39 Apr 2015.

- Li, Yulong; Liu, Xiaojing (2017). Integration of iPad-Based M-Learning into a Creative Engineering Module in a Secondary School in England. Turkish Online Journal of Educational Technology - TOJET, v16 n2 p4357 Apr 2017.

- Mahande, Ridwan Daud; Susanto, Adhi; Surjono, Herman Dwi (2017). The Dynamics of Mobile Learning Utilization in Vocational Education: Frame Model Perspective Review. Turkish Online Journal of Educational Technology - TOJET, v16 n4 p65-76 Oct 2017.

- Mahdi, Hassan Saleh (2018). Effectiveness of Mobile Devices on Vocabulary Learning: A Meta-Analysis. Journal of Educational Computing Research, v56 n1 p134-154 Mar 2018.

- Maketo, Lydia (2018). Mobile Learning Zimbabwe-Lecturers' Perceptions. International Association for Development of the Information Society, Paper presented at the International Association for Development of the Information Society (IADIS) International Conference on Mobile Learning (14th, Lisbon, Portugal, Apr 14-16, 2018).

- Park, Kunsoon; Park, Narang; Heo, Wookjae; Gustafson, Kim (2019). What Prompts College Students to Participate in Online Surveys? International Education Studies, v12 n1 p69-79 2019.

- Pfaffe, Linda D. (2014). Using the SAMR Model as a Framework for Evaluating mLearning Activities and Supporting a Transformation of Learning. ProQuest LLC, Ed.D. Dissertation, St. John's University (New York), School of Education and Human Service.

- Pillai, Rajasshrie; Sivathanu, Brijesh (2018). An Empirical Study on the Adoption of M-Learning Apps among IT/ITeS Employees. Interactive Technology and Smart Education, v15 n3 p182-204 2018.

- Roberts, Lynne D.; Allen, Peter J. (2015). Exploring Ethical Issues Associated with Using Online Surveys in Educational Research. Educational Research and Evaluation, v21 n2 p95-108 2015.

- Sanderson, Nicole; Hanbidge, Alice Schmidt (2017). Educators Adopting M-Learning: Is It Sustainable in Higher Education? International Association for Development of the Information Society, Paper presented at the International Association for Development of the Information Society (IADIS) International Conference on Mobile Learning (13th, Budapest, Hungary, Apr 10-12, 2017).

- Smith, C. hristine B. (June, 1997). "Casting the net: surveying an Internet population." Journal of ComputerMediated Communication, v3 n1 June 1997.

- The Public Authority for Applied Education and Training (PAAET)" Archived (September 17, 2008). Available online at the Wayback MachineWayback Machine, Ministry of Information, Kuwait. 